associated, in the three other animals, with pressure recording within the common bile duct or the gall-bladder or with bile-flow measurement.

A slow rhythmic electrical activity was frequently recorded at the level of the gall-bladder and common bile duct. However, the preparation was rapidly damaged by vesicular sclerosis. The frequency of these "pace-setter potentials \# was about $4 / \mathrm{mm}$ which is very similar to the basal electrical rhythm in the antrum. No rapid activity (spike potentials) was recorded, even when the gall-bladder was subjected to the most important movements. The observations made with respect to this were artifacts depending on displacements of the electrodes. At the level of the Oddi sphincter, a spiking activity was very often recorded in the form of more or less dense bursts, still occuring at a frequency of about $4 / \mathrm{mm}$. This activity accompanied the fluctuations of the intra-choledochal pressure. However, it is striking that when the rapid activity failed to appear at the level of the pyloric antrum, the rapid activity derived at the level of the Oddi sphincter tended to reorganize according to a duodenal rhythm, thus behaving as the whole duodenal bulb.

Consequently, in the pig a slow antrum like rhythmic activity seems to exist at the level of the bile ducts. The rapid activity of the Oddi sphincter seems to be subjected, like the adjacent musculature of the duodenal bulb to the extension of an antrum originating influence.

\title{
RÉALISATION D'ANUS ARTIFICIELS CHEZ LE LAPIN: MISE EN ÉVIDENCE DU DÉTERMINISME ET ÉTUDE DU RYTHME NYCTHÉMERAL DE LA CAECOTROPHIE
}

\author{
P. BEZILLE, F. GALLOUIN et H. LE BARS \\ Institut national agronomique, I. N.R. A., \\ 16, rue Claude-Bernard, \\ 75231 Paris Cedex 05
}

La cæcotrophie chez le lapin est une composante de son comportement alimentaire puisque, de cette façon, il réingère directement à l'anus des "fèces " d'un type très particulier riches en protides et en vitamines. Ces cæcotrophes ou fèces molles ne rentrent pas en contact avec le sol : le lapin est donc informé du moment de leur transit dans le colon ou le rectum et, de ce fait, il peut aller les chercher lors de leur émission à l'anus. Le rectum est-il l'organe sensible ?

Pour vérifier cette hypothèse nous avons pratiqué des anus artificiels entre la terminaison du colon et le début du rectum. Le transit normal par le rectum est de ce fait, momentanément interrompu (pendant 3 semaines).

Pendant cette période, le lapin perd à son insu des cæcotrophes en quantité importante alors que des animaux témoins observés pendant la même période n'en perdent pratiquement pas.

Lors de la cicatrisation de l'anus artificiel et du rétablissement du transit normal par le rectum le lapin ne perd plus de caecotrophes.

On peut donc conclure que le rectum était stimulé par le passage des cæcotrophes. Quelle est la nature des récepteurs sensibles à ce niveau? En comparant la morphologie d'un cæcotrophe à celle d'une crotte "normale " on peut penser qu'il s'agit de la mise en jeux de mécanorécepteurs du rectum. 
Cette technique, associée à un collecteur de fèces par fraction nous a permis, en outre, de mettre en évidence les faits suivants :

Io Il y a un rythme nycthéméral de la cæcotrophie, ou plus exactement de la production des cæcotrophes. Cette émission se fait en une seule période qui dure 2 à 3 heures. Elle a lieu, dans les conditions de notre laboratoire, entre 6 heures et II heures du matin.

$2^{\circ}$ Elle est précédée d'une période de 30 à 60 minutes pendant laquelle aucun type de fèces n'est émis. En d'autres termes, il y a une vidange complète du colon et du rectum des fèces dures qu'ils contenaient avant le passage des cæcotrophes.

\section{En conclusion}

Cette technique physiologique, nous semble intéressante à utiliser pour l'étude de la cæcotrophie chez le lapin, elle permet en outre, d'extérioriser la muqueuse du colon et, de ce fait, peut être applicable à l'étude de l'absorption, à ce niveau, de nombreuses substances médicamenteuses.

\section{SUMMARY}

\section{REALIZATION OF ARTIFICIAL ANUSES IN THE RABBIT. PROVING OF THE DETERMINISM AND STUDY OF THE CIRCADIAN RHYTHM IN CAECOTROPHY}

Feeding behaviour in the rabbit is characterized by caecotrophy. In this way, the animal reingests directly at the anus "faeces " of a very particular type, containing much protein and vitamins. As these caocotrophes or soft faeces do not touch the soil, the rabbit is informed about the moment of their transit in the colon or the rectum and, for that reason, it can fetch them when they leave the anus. Is the rectum the sensitive organ?

In order to verify this hypothesis, we realized artificial anuses between the end of the colon and the beginning of the rectum. The normal transit through the rectum was thus interrupted momentarily (for 3 weeks).

During this period, the rabbit lost, without knowing it, large amounts of caecotrophes, whereas the control animals, observed during the same period, almost did not lose any.

After cicatrization of the artificial anus and restoring of the normal transit through the rectum the rabbit did not lose any caecotrophes

Therefore, it is to be concluded that the rectum is stimulated by the passage of the caecotrophes. Which kind of sensitive receptors exist at this level? By comparing the morphology of caecotrophes with that of "normal " faeces, the setting into action of mechano-receptors in the rectum can be imagined.

This technique associated with utilization of a fraction collector of faeces allowed in addition to determine the following facts :

$I^{\circ}$ Reproduction of caecotrophes is subjected to a circadian rhythm. The emission lasts 2-3 hours, and under our experimental conditions, it takes place between 6 and I I a. $\mathrm{m}$.

$2^{\circ}$ It is preceded by a period of $30-60$ minutes during which no kind of faeces are emitted. So, the colon and rectum are totally empted from the hard faeces they contained before the passage of the caecotrophes.

\section{Conclusion}

This physiological technique seems to be interesting for studying caecotrophy in the rabbit. It also allows to exteriorize the mucosa of the colon and can therefore be used for studying the absorption of several medicinal substances at this level. 